НАУКИ ПРО ЗЕМЛЮ

GEOSCIENCES

https://doi.org/10.15407/dopovidi2021.02.083

УдК $528+550.837+553.98$

\author{
М.А. Якимчук ${ }^{1}$, I.М. Корчагін ${ }^{2}$ \\ ${ }^{1}$ Інститут прикладних проблем екології, геофізики і геохімії, Київ \\ ${ }^{2}$ Інститут геофізики ім. С.І. Субботіна НАН України, Київ \\ E-mail: yakymchuk@gmail.com, korchagin.i.n@gmail.com
}

\title{
Особливості геологічної будови ділянки посадки марсохода NASA Perseverance на Марсі за результатами частотно-резонансної обробки знімків з космічних апаратів
}

Представлено членом-кореспондентом НАН України М.А. Якимчуком

Наведено результати експериментальних досліджень на Марсі на локальній діляниі посадки марсохода NASA Perseverance, в районі кратера Jеzего і на площі в північній частині планети. Дослідження рекогносцирувального характеру проведені із застосуванням методів частотно-резонансної обробки та інтерпретації знімків ділянок обстеження з космічних апаратів з метою вивчення особливостей їх геологічної будови. Інструментальні виміри показали, що ділянка посадки марсохода розташована в межах вулканічної структури, заповненої мергелями. На поверхні в зоні посадки виявлені уламки кременистих порід. У районі розташування кратера Јеzего інструментальними вимірами встановлено (підтверджено) наявність у розрізі планети 8 типів вулканічних споруд, заповнених: 1) сіллю; 2) вапняками; 3) доломітами; 4) мергелями; 5) кременистими породами; 6) базальтами; 7) ультрамафічними породами; 8) кімберлітами. Обстеженням окремих площ, планети підтверджений факт наявності в ї складі лише 27 відомих на Землі хімічних елементів. До відсутніх на Марсі хімічних елементів належить також кисень. Відсутність кисню на Марсі свідчить про те, що на планеті немає води, а отже, $і$ льоду в полярних областях. У районі північного полюса Марса виявлені крупні вулканічні структури, заповнені сіллю. Виявлені на Марсі численні вулканічні комплекси, заповнені породами різного складу, є важливими аргументами на користь вулканічної моделі формування зовнішнього вигляду планети. Результати досліджень свідчать про принципову можливість використання даних дистанційного зондування планет і супутників Сонячної системи (знімків з космічних апаратів, посадочних модулів і телескопів) для вивчення внутрішньої будови об'єктів обстеження $і$ складу присутніх на них порід, мінералів і хімічних елементів. Частотно-резонансна технологія обробки супутникових знімків і фотознімків може бути використана для детальних досліджень на планетах і супутниках Сонячної системи в рамках великих наукових проєктів їх вивчення. Апробована мобільна технологія може також знайти застосування під час вибору місць відбору зразків порід для марсохода.

Ключові слова: Марс, марсохід NASA Pеrseverance, супутник, хімічний елемент, глибинна будова, вулкан, розріз, нафта, газ, водень, супутникові дані, фотознімок, прямі пошуки, мобільна технологія, аномалія, обробка даних ДЗ3, інтерпретація.

Ц и т у в ан н я: Якимчук М.А., Корчагін І.М. Особливості геологічної будови ділянки посадки марсохода NASA Perseverance на Марсі за результатами частотно-резонансної обробки знімків з космічних апаратів. Допов. Наи. акад. наук Укр. 2021. № 2. С. 83-90. https://doi.org/10.15407/dopovidi2021.02.083 
Результати цілеспрямованої апробації в останні роки мобільної прямопошукової технології частотно-резонансної обробки і декодування супутникових знімків і фотознімків свідчать про доцільність більшої уваги до вивчення вулканічних процесів на Землі і їх впливу на формування зовнішнього вигляду і внутрішньої будови планети [1]. Експериментальними дослідженнями підтверджена наявність глибинних каналів (вулканічних комплексів) різного типу в різних регіонах земної кулі [2-6]. У зв’язку з цим останнім часом під час досліджень з метою пошуків корисних копалин виконуються додаткові виміри, спрямовані на встановлення наявності (відсутності) глибинних каналів (вулканів) у межах великих площ і локальних ділянок обстеження.

Апробована технологія частотно-резонансної обробки супутникових знімків і фотознімків дає також можливість проводити експериментальні дослідження з метою вивчення особливостей будови різних об’єктів Сонячної системи і далекого космосу. На даний момент накопичено значний обсяг даних дистанційного зондування планет і супутників Сонячної системи з космічних апаратів, посадочних модулів супутників, а також з космічних телескопів. Вивчення внутрішньої будови планет і супутників Сонячної системи шляхом обробки космо- і фотознімків може дати додаткову інформацію для розуміння особливостей геологічної еволюції Землі і процесів формування різних структурно-тектонічних елементів планети. Деякі результати експериментальних досліджень такого характеру наведені в [3, 5]. У статті [5] розглядалися матеріали обстеження локальної ділянки посадки на Місяці 1 грудня 2020 р. китайського місячного апарата Chang'e 5. У цьому повідомленні наводяться попередні результати обстеження з використанням розробленої технології місця посадки марсохода NASA Perseverance в кратері Jezero на Марсі 18 лютого 2021 р.

Методи досліджень. В експериментальних дослідженнях на Землі, а також планетах і супутниках Сонячної системи використовується мобільна прямопошукова технологія частотно-резонансної обробки і декодування супутникових знімків, а також фотознімків із посадочних апаратів і космічних телескопів [2-6]. Окремі компоненти використовуваної технології розроблені на принципах “речовинної” парадигми геофізичних досліджень, сутність якої полягає в пошуку конкретної (шуканої в кожному окремому випадку) речовини. В основі розроблених методів лежать виявлені Ніколою Тесла в 1899 р. стоячі електричні хвилі. Мобільна технологія в цілому, а також окремі їі методи активно використовуються останнім часом для вивчення глибинної будови Землі і пошуків скупчень вуглеводнів на початкових етапах геологорозвідувального процесу, в тому числі і для інтегральної оцінки перспектив нафтогазоносності великих і важкодоступних блоків і площ. Матеріали щодо апробації та практичного застосування мобільної технології розглядалися в багатьох статтях і матеріалах конференцій, у тому числі і в [2-6].

У модифікованих версіях методів частотно-резонансної обробки супутникових знімків і фотознімків, а також вертикального зондування (сканування) розрізу використовуються існуючі бази (набори, колекції) порід. Колекція зразків осадових порід земного походження (зафіксованих у грязьових вулканах під час обробки на Землі) включає 10 груп, а метаморфічних і магматичних - 18 груп. На рис. 1 зображені фотографії двох зразків з 9-ї (мергелі) і 10-ї (кременисті) груп осадових порід, сигнали від яких фіксуються під час частотно-резонансної обробки космознімків Марса. Фотографії використовуваних у процесі інструментальних вимірювань наборів зразків порід запозичені з сайта http://rockref.vsegei.ru/petro/. 

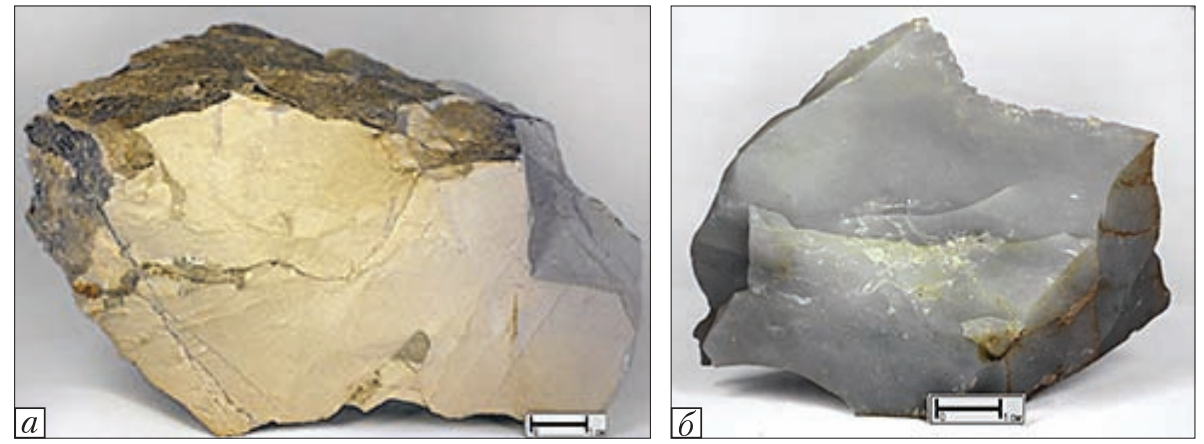

Puc. 1. Фотографії зразків мергель кременистий $(a)$ з 9-ї (мергелі) і кремній халцедоновий (б) з 10-ї (кременисті) груп осадових порід, резонансні частоти яких фіксувалися під час обробки знімків

Локальна ділянка посадки марсохода. У процесі частотно-резонансної обробки першого знімка (рис. 2) місця посадки з марсохода NASA Perseverance [7] з використанням частот хімічних елементів, корисних копалин і зразків порід, традиційно використовуваних під час досліджень на Землі, зареєстровані сигнали (відгуки) від водню і окремих зразків осадових порід 9-ї групи (мергелів).

3 наявних у базі 10 зразків мергелів відгуки зафіксовані тільки від одного з них - мергелю кременистого (див. рис. 1, $a$ ).

Під час обробки знімка з поверхні зареєстровані сигнали від водню, дейтерію і хлору.

Від самого зразка мергель кременистий зафіксовані сигнали на частотах водню, хлору i від комбінації хлору і водню. Від цього зразка зафіксовані також слабкі сигнали на частотах заліза і сигнали від комбінації хлор-залізо-водень.

Під час обробки знімка на рис. 2 зафіксовані відгуки на частотах заліза, а також від комбінації хімічних елементів хлор-водень і хлор-залізо-водень.

У процесі обробки локального фрагмента знімка на рис. 2 (верхній прямокутник) зареєстровані відгуки тільки від одного зразка 10-ї групи осадових (кременистих) порід кремнію халцедонового (див. рис. 1,6$)$.

Аналогічні результати отримані також під час обробки частини фотографії на рис. 2 у центральному прямокутнику, а також у найменшому, нижньому.

Від зразка кремній халцедоновий відгуки отримані від водню, хлору, заліза (інтенсивний) і кобальту. Зареєстровані також слабкі сигнали від комбінації хлор-водень і інтенсивні - від хлор-водень-залізо.

Під час обробки знімка в центральному прямокутнику отримані відгуки від водню, хлору, кобальту і заліза.

У процесі додаткової обробки всього знімка на рис. 2 зареєстровані слабкі відгуки від зразка кремній халцедоновий (див. рис. 1, б).

На рис. 3, а і б показані знімки поверхні Марса 3 марсохода під час його наближення до місця посадки.

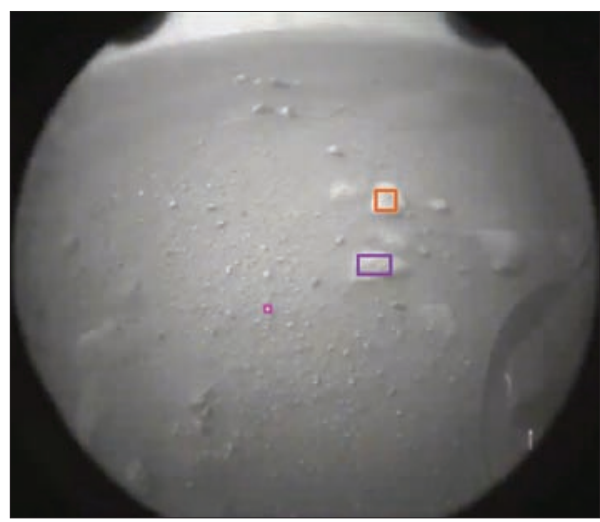

$\boldsymbol{P u c . ~ 2 . ~ З н і м о к ~ м і с ц я ~ п о с а д к и ~ з ~ м а р с о х о - ~}$ да NASA Perseverance в кратері Jezero на Марсі 18 лютого 2021 р. [7] 

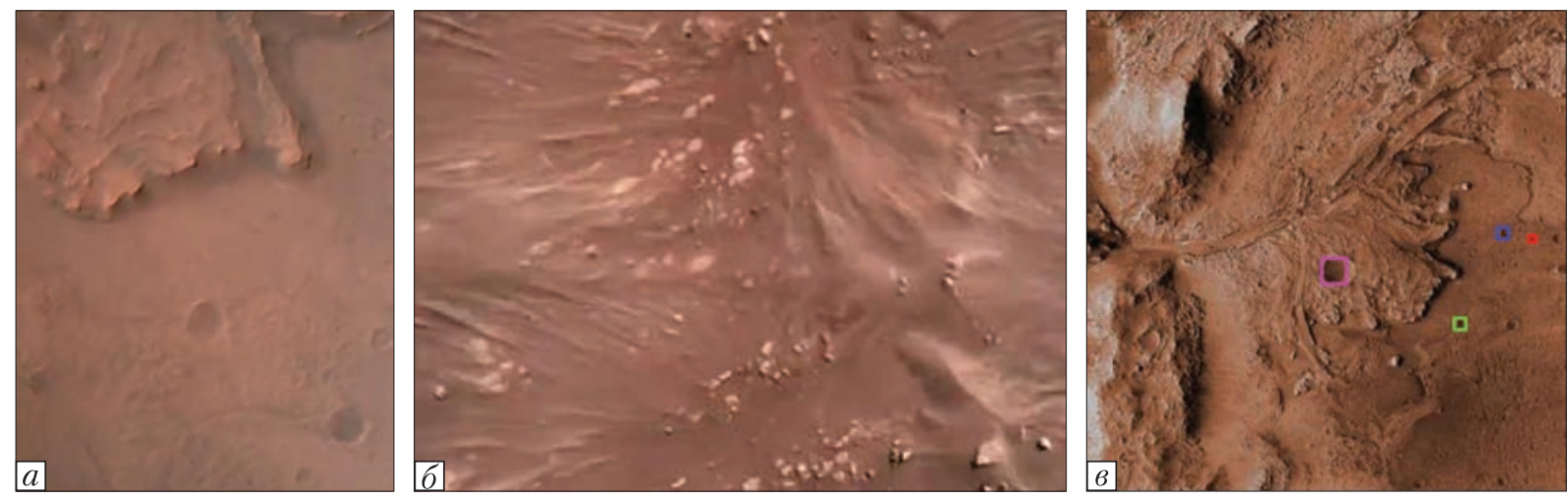

$\boldsymbol{P u c . 3 . ~ Ф о т о з о б р а ж е н н я ~ р а и ̆ о н у ~ п о с а д к и ~ в ~ к р а т е р і ~ J e z e r o ~ н а ~ M a p c i ~ з ~ м а р с о х о д а ~ N A S A ~ P e r s e v e r a n c e ~}(a, 6)$ i супутника (в) [8]

У процесі частотно-резонансної обробки зображення на рис. 3, б з поверхні зареєстровані відгуки від окремих зразків 9-ї (мергелі) та 10-ї (кременисті) груп осадових порід.

У процесі сканування розрізу з різними кроками відгуки від мергелів зафіксовані з поверхні і простежені до 295,6 км (корінь вулкана мергелів). Сигнали від кременистих порід отримані тільки з інтервалу глибин 0-293 м.

Район посадки марсохода в кратері Jezero. Обстеження району посадки марсохода проведено до 18 лютого 2021 р. Фотозображення району, використаних для частотно-резонансної обробки, запозичені з сайта [8]. При цьому відзначимо, що інструментальними вимірами встановлена інформативність (придатність для частотно-резонансної обробки) супутникового знімка району, зображеного на рис. 3, в.

У процесі частотно-резонансної обробки знімка району посадки з супутника Марса (див. рис. 3, в) з поверхні зареєстровані відгуки від таких хімічних елементів: водень, дейтерій, хлор, залізо, кобальт, літій, берилій, аргон, нікель, калій, скандій, кальцій, титан, гелій, хром, марганець, мідь, ванадій, цинк, гелій, германій, миш'як, селен, бром, бор, азот, натрій.

На обстеженій площі зафіксовані сигнали від солі й окремих зразків 8-ї (доломіти), 9-ї (мергелі), 10-ї (кременисті) груп осадових порід, а також 6-ї (базальти), 7-ї (ультрамафічні породи), 11-ї (кімберліти) і 15-ї груп магматичних порід.

На рис. 3, в прямокутниками позначені контури чотирьох вулканічних утворень, фрагменти супутникового знімка над якими оброблені окремо.

Під час частотно-резонансної обробки частини фотографії в лівому (найбільшому) прямокутнику зареєстровані відгуки від окремих зразків 8-ї групи осадових порід (доломіти). 3 усього набору зразків доломітів сигнали отримані тільки від одного - доломіту кавернозного.

У процесі обробки частини фотографії в нижньому прямокутнику в розрізі встановлено наявність вулкана, заповненого окремими зразками 10-і (кременисті), у верхньому прямокутнику з синім контуром - 7-ї (вапняки) і в прямокутнику з червоним контуром - 9-ї (мергелі) груп осадових порід. На рис. 3, $а$ вулкан кременистих порід розташований практично в центрі.

Соляні вулкани на півночі Марса. У багатьох публікаціях та інформаційних повідомленнях, у тому числі і в [9, 10], наводиться інформація про виявлення льоду в полярних 

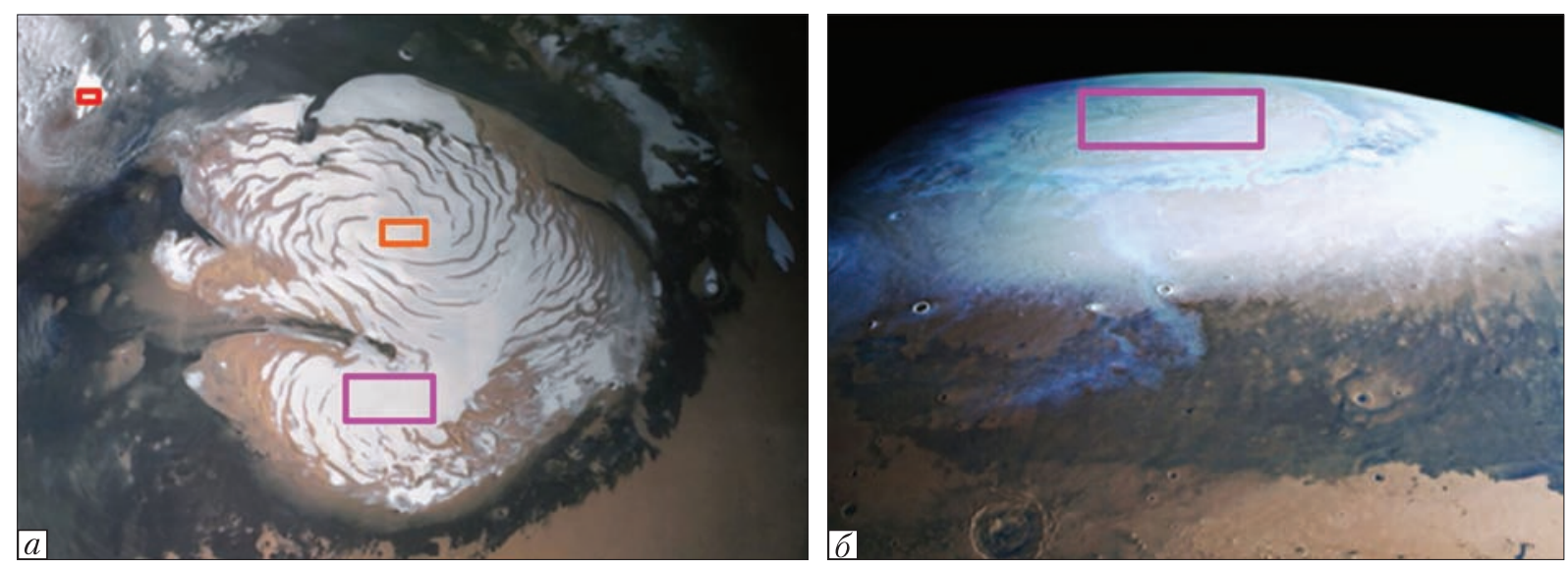

Puc. 4. Фрагменти супутникових знімків північного полюса Марса $[9,10]$

областях Марса. У зв’язку з цим деякий обсяг інструментальних вимірювань виконано під час обробки супутникових знімків північної частини Марса.

Під час частотно-резонансної обробки супутникового знімка на рис. 4, $a$ [9] з поверхні зареєстровані сигнали від водню, солі і окремих зразків 8-ї (доломіти) і 9-ї (мергелі) груп осадових порід, а також 6-ї (базальти) і 11-ї (кімберліти) груп магматичних порід. Нижня кромка соляного вулкана визначена скануванням на глибині 295,6 км.

У межах нижнього прямокутного контуру на рис. 4, $a$ на поверхні 295,6 км з верхньої частини розрізу зареєстровані сигнали від солі і окремих зразків з груп доломіти, мергелі, базальти і кімберліти. Нижня кромка солі скануванням з поверхні, крок 1 м, визначена на глибині 911 м. На цій глибині з верхньої частини розрізу відгуки від окремих зразків з груп доломіти, мергелі, базальти і кімберліти були відсутні, а з нижньої частини - зареєстровані.

На поверхні 0 м з верхньої частини розрізу зафіксовані сигнали від водню, що свідчить про його міграцію в простір над поверхнею планети.

Скануванням розрізу з 911 м, крок 1 см, верхні кромки доломітів, мергелів, базальтів і кімберлітів визначені в інтервалі глибин 912-913 м.

Під час обробки частини фотографії в центральному прямокутнику (див. рис. 4, $a$ ) зареєстровані сигнали тільки від солі. Відгуків від осадових і магматичних порід в цій частині знімка не отримано. Корінь соляного вулкана визначено скануванням на глибині 295,6 км. Такі результати обробки дають підставу зробити висновок, що в цій частині площі обстеження на Марсі розташований соляний вулкан, сіль з якого перекрила вулканічні споруди доломітів, мергелів, базальтів і кімберлітів, як у межах нижнього прямокутного контуру, так і в інших частинах площі обстеження.

За результатами обробки невеликого фрагмента знімка в прямокутному контурі в лівій верхній частині рис. 4, $а$ також встановлено наявність соляного вулкана з коренем на глибині 295,6 км.

На рис. 4, б зображений ще один супутниковий знімок північного полюса Марса [10]. У межах прямокутного контуру на цьому знімку також зареєстровані сигнали від солі і окремих зразків з груп доломіти, мергелі, базальти і кімберліти. Скануванням розрізу з по- 
верхні, крок 1 м, нижня кромка солі визначена на глибині 1513 м. На глибині 1510 м з верхньої частини розрізу відгуки від груп осадових і магматичних порід не отримані.

Скануванням розрізу з 1510 м, крок 1 см, верхні кромки доломітів, мергелів, базальтів і кімберлітів визначені в інтервалі глибин 1512-1516 м, а нижні кромки (корені вулканів) на глибині 295,6 км.

Результати частотно-резонансної обробки частини фотографії північного полюса Марса (рис. 4, б) також свідчать про наявність у цьому регіоні планети великого соляного вулкана, сіллю з якого перекриті вулканічні комплекси доломітів, мергелів, базальтів і кімберлітів.

Короткі коментарі та висновки. Проведені експериментальні дослідження показали насамперед принципову можливість використання даних дистанційного зондування планет і супутників Сонячної системи (знімків з космічних апаратів, посадочних модулів і телескопів) для вивчення внутрішньої будови об'єктів дослідження, а також складу присутніх на них порід і мінералів з аналогами на землі і хімічних елементів.

Результати оперативно проведених експериментальних досліджень дали можливість отримати таку інформацію про геологічну будову місця посадки марсохода в районі розташування кратера Jezero на Марсі.

1. Локальна ділянка посадки марсохода розташована в межах вулканічної структури, заповненої мергелями. 3 використовуваного набору зразків мергелів у розрізі на місці посадки встановлено наявність тільки одного зразка цих порід - мергелю кварцитового.

2. На ділянці посадки на поверхні “розкидані” уламки порід світлого кольору - кремнію халцедонового. Можна припустити, що це уламки з розташованих у цьому районі вулканічних комплексів, заповнених кременистими породами (окремі зразки 10-ї групи осадових порід з використовуваної під час інструментальних вимірювань колекції).

3. У районі розташування кратера Jezero інструментальними вимірами встановлено (підтверджено) наявність у розрізі планети 8 типів вулканічних утворень, заповнених: 1) сіллю; зразками з груп: 2) вапняки; 3) доломіти; 4) мергелі; 5) кременисті породи; 6 ) базальти; 7) ультрамафічні породи; 8) кімберліти.

4. Під час обстеження окремих площ планети підтверджений факт наявності в їі складі лише 27 відомих на Землі хімічних елементів. До відсутніх на Марсі хімічних елементів належить також кисень.

5. Відсутність кисню на Марсі свідчить також про те, що на планеті немає (і не було) води, а отже, і льоду в полярних областях. Виявлення в районі північного полюса Марса великих вулканічних комплексів, заповнених сіллю, можна вважати додатковим аргументом на користь відсутності води (а отже, і льоду) на планеті.

6. Виявлення на Марсі численних вулканічних комплексів, заповнених породами різного складу, можна вважати важливим аргументом на користь вулканічної моделі [1] формування зовнішнього вигляду планети.

Оцінюючи результати оперативно проведених експериментальних робіт, можна констатувати, що мобільна частотно-резонансна технологія обробки супутникових знімків і фотознімків може бути використана для детальних досліджень на планетах і супутниках Сонячної системи в рамках великих наукових проєктів їх вивчення. 


\section{ЦИТОВАНА ЛІТЕРАТУРА}

1. Багдасарова М.В. Дегазация Земли - глобальный процесс, формирующий флюидогенные полезные ископаемые (в том числе месторождения нефти и газа). Глубинная нефть. 2014. № 10. С. 1621-1644.

2. Якимчук М.А., Корчагін І.М. Нові свідчення на користь абіогенного генезису вуглеводнів за результатами апробації прямопошукових методів у різних регіонах світу. Допов. Наи. акад. наук Укр. 2020. № 9. C. 53-60. https://doi.org/10.15407/dopovidi2020.09.053

3. Якимчук М.А., Корчагін І.М. Результати застосування прямопошукових геофізичних методів для виявлення і локалізації зон скупчення та міграції водню в розрізах Землі і Місяця. Допов. Нащ. акад. наук Укр. 2021. № 1. С. 65-76. https://doi.org/10.15407/dopovidi2021.01.065

4. Якимчук Н.А., Корчагин И.Н., Бахмутов В.Г., Соловьев В.Д. Геофизические исследования в Украинской морской антарктической экспедиции 2018 г.: мобильная измерительная аппаратура, инновационные прямопоисковые методы, новые результаты. Геоінформатика. 2019. № 1. С. 5-27.

5. Якимчук Н.А., Корчагин И.Н. О возможности применения технологии частотно-резонансной обработки спутниковых снимков и фотоснимков для изучения объектов Солнечной системы и дальнего космоса. Геоінформатика. 2020. № 2. С. 98-108.

6. Якимчук Н.А., Корчагин И.Н. Прямопоисковая технология частотно-резонансной обработки спутниковых снимков и фотоснимков: результаты использования для определения участков миграции газа и водорода на поверхность и в атмосферу. Геоінформатика. 2020. № 3. С. 3-28.

7. Марсохід NASA Perseverance сів на Марсі. Українська правда. URL: https://www.pravda.com.ua/news/ 2021/02/18/7283947/. (Дата звернення: 19.02.2021).

8. Photo tour of Jezero Crater: Here's where Perseverance will land on Mars. Live Science. URL: https://www. livescience.com/mars-jezero-crater-perseverance-photos.html. (Дата звернення: 21.02.2021).

9. Расшифровка возраста льда на северном полюсе Марса. InFuture ${ }^{\text {ru }}$. URL: https://infuture.ru/article/ 21872. (Дата звернення: 10.02.2021).

10. Two new images show Mars' icy poles and pockmarked surface. Digital Trends. URL: https://www. digitaltrends.com/cool-tech/mars-esa-images-poles/. (Дата звернення: 10.02.2021).

Надійшло до редакції 26.02.2021

\section{REFERENCES}

1. Bagdasarova, M.V. (2014). Degassing of the Earth - a global process, formative fluidogennye minerals (including oil and gas). Glubin. neft, No. 10, pp. 1621-1644 (in Russian).

2. Yakymchuk, M.A. \& Korchagin, I.M. (2020). New evidence in favor of the abiogenic genesis of hydrocarbons from the results of the testing of direct-prospecting methods in various regions of the world. Dopov. Nac. akad. nauk Ukr., No. 9, pp. 53-60 (in Ukrainian). https://doi.org/10.15407/dopovidi2020.09.053

3. Yakymchuk, M.A. \& Korchagin, I.M. (2021). The results of direct-prospecting geophysical methods used for the detection and localization of zones of hydrogen accumulation and migration in the Earth and the Moon cross-sections. Dopov. Nac. akad. nauk Ukr., No. 1, pp. 65-76 (in Ukrainian). https://doi.org/10.15407/ dopovidi2021.01.065

4. Yakymchuk, N. A., Korchagin, I. N., Bakhmutov, V. G. \& Solovjev, V. D. (2019). Geophysical investigation in the Ukrainian marine Antarctic expedition of 2018: mobile measuring equipment, innovative directprospecting methods, new results. Geoinformatika, No.1, pp. 5-27 (in Russian).

5. Yakymchuk, N. A., Korchagin, I. N. (2020). On the possibility of application the frequency-resonance technology of satellite images and photos images processing for studying objects of the solar system and far space. Geoinformatika, No.2, pp. 98-108 (in Russian).

6. Yakymchuk, N. A., Korchagin, I. N. (2020). Direct-prospecting technology of frequency-resonant processing of satellite images and photos images: results of use for determining areas of gas and hydrogen migration to the surface and in the atmosphere. Geoinformatika, No. 3, pp. 3-28 (in Russian).

7. NASA's Perseverance rover landed on Mars. Ukrainska pravda. Retrieved from https://www.pravda.com.ua/ news $/ 2021 / 02 / 18 / 7283947 /$

8. Photo tour of Jezero Crater: Here's where Perseverance will land on Mars. Live Science. Retrieved from https://www.livescience.com/mars-jezero-crater-perseverance-photos.html 
9. Deciphering the age of ice at the north pole of Mars. InFuture ${ }^{\text {.ru }}$. Retrieved from https://infuture.ru/ article $/ 21872$

10. Two new images show Mars' icy poles and pockmarked surface. Digital Trends. Retrieved from https://www. digitaltrends.com/cool-tech/mars-esa-images-poles/

Received 26.02.2021

\author{
M.A. Yakymchuk ${ }^{1}$, I.M. Korchagin ${ }^{2}$ \\ ${ }^{1}$ Institute of Applied Problems of Ecology, Geophysics and Geochemistry, Kyiv \\ ${ }^{2}$ S.I. Subbotin Institute of Geophysics of the NAS of Ukraine, Kyiv \\ E-mail: yakymchuk@gmail.com, korchagin.i.n@gmail.com \\ FEATURES OF THE GEOLOGICAL STRUCTURE \\ OF NASA PERSEVERANCE ROVER LANDING SITE \\ ON MARS BASED ON THE RESULTS OF FREQUENCY-RESONANCE \\ PROCESSING OF IMAGES FROM SPACECRAFTS
}

The results of experimental studies on the Mars at the local landing site of the NASA Perseverance rover, in the Jezero crater area and on an area in the northern part of the planet are presented. Reconnaissance studies were carried out using the methods of frequency-resonance processing and the interpretation of images of survey sites from spacecrafts in order to study the features of their geological structure. Instrumental measurements showed that the landing site of the rover is located within a volcanic structure, filled with marls. Fragments of siliceous rocks were found on the surface in the landing zone. In a vicinity of the Jezero crater, the instrumental measurements have established (confirmed) the presence in the planet's cross-section, of 8 types of volcanic structures filled with: 1) salt; 2) limestones; 3) dolomites; 4) marls; 5) siliceous rocks; 6) basalts; 7) ultramafic rocks; 8) kimberlites. Examination of individual areas of the planet confirmed the presence of only 27 chemical elements known on the Earth. Oxygen also belongs to the chemical elements, absent on the Mars. The lack of oxygen in the composition of the Mars indicates that there is no water on the planet, and, therefore, no ice in the Polar Regions. Large volcanic structures filled with salt have been discovered in the area near the north pole of the Mars. The numerous volcanic complexes found on the Mars filled with rocks of various compositions are important arguments in favor of a volcanic model of formation of the planet outer appearance. The research results indicate the fundamental possibility of using the data from remote sensing of planets and satellites of the solar system (images from spacecrafts, landing modules, and telescopes) to study the internal structure of survey objects and the composition of rocks, minerals, and chemical elements, present on them. The frequencyresonance technology of satellite images and the photo images processing can be used to carry out detailed studies on planets and satellites of the solar system in the framework of large scientific projects to study them. The proven mobile technology can also find applications in the selection of rock sampling sites for the rover.

Keywords: Mars, NASA Perseverance rover, satellite, chemical element, deep structure, volcano, cross-section, oil, gas, hydrogen, satellite data, photograph, direct searches, mobile technology, anomaly, remote sensing data processing, interpretation. 